\title{
Kegiatan Simpan Pinjam Khusus Perempuan di Kecamatan Semparuk, Sambas
}

\author{
Study of Women's Savings and Loan Activity in Sub-Distric Semparuk, Sambas \\ Hamdi $^{\star 1}$, Hartrisari Hardjomidjojo ${ }^{2 \#}$, Amiruddin Saleh ${ }^{3 \#}$ \\ ${ }^{1}$ Politeknik Terpikat Sambas \\ Jl. Raya Sejangkung Komplek Pendidikan Sambas \\ ${ }^{2}$ Departemen Teknologi Industri Pertanian, Fakultas Teknologi Pertanian, Institut Pertanian Bogor \\ ${ }^{3}$ Departemen Komunikasi dan Pengembangan Masyarakat, Fakultas Ekologi Manusia, Institut Pertanian Bogor \\ \#JI. Kamper, Kampus IPB Darmaga, Bogor 16680
}

\begin{abstract}
ABSTRAK
Kegiatan Simpan Pinjam khusus Perempuan (SPP) adalah upaya pemerintah Indonesia untuk mengembangkan potensi kegiatan simpan pinjam perdesaan, kemudahan akses pendanaan usaha skala mikro, pemenuhan kebutuhan pendanaan sosial dasar, dan memperkuat kelembagaan kegiatan kaum perempuan serta mendorong pengurangan rumah tangga miskin dan penciptaan lapangan kerja. Tujuan kajian adalah mengidentifikasi masalah, menganalisis kekuatan, kelemahan, peluang dan ancaman pada kegiatan SPP serta menyusun strategi perbaikannya di unit pengelola kegiatan (UPK) Kecamatan Semparuk Kabupaten Sambas. Data primer dikumpulkan dari pemanfaat dana dengan observasi dan teknik wawancara, dan data sekunder didapatkan dari studi kepustakaan, antara lain jurnal penelitian, buletin, tesis, buku, Petunjuk Teknis Operasional (PTO) PNPM-MPd, laporan hasil kegiatan program, serta data kegiatan SPP reguler dan perguliran dana SPP. Wawancara dilakukan dengan 50 responden yang memanfaatkan kredit selama tiga tahun berturut-turut tanpa putus dan empat orang pelaku program. Data yang diperoleh selanjutnya dianalisis secara deskriptif dan kajian strategi menggunakan analisis matriks Internal Factor Evaluation, matriks External Factor Evaluation, matriks Internal Eksternal, analisis matriks Strengths, Weakness, Opportunities and Threats serta Quantitative Strategic Planning Matrix. Hasil penelitian memperlihatkan masalah-masalah yang teridentifikasi: pemberdayaan ekonomi rumah tangga miskin (RTM) belum dilaksanakan, tabungan anggota tidak berkembang, proses pencairan kredit yang relatif lama, belum maksimalnya peran pelaku program dalam fasilitasi kelompok terutama dalam pengembangan usaha anggota. Beberapa alternatif strategi yang dapat dilaksanakan UPK secara urutan prioritas adalah: meningkatkan pelayanan, melakukan perluasan pasar dan jaringan pemasaran kredit, memaksimalkan peran pelaku program, mempertahankan komitmen terhadap pengembangan SPP, meningkatkan promosi program, meningkatkan pembinaan kelompok, dan pengembangan produk simpanan dan pinjaman.
\end{abstract}

Kata kunci: simpan pinjam khusus perempuan, pemberdayaan, unit pengelola kegiatan

\section{ABSTRACT}

Women's savings and loan (SPP) activity is Indonesian government effort to develop rural savings and loan's potency, access facility to micro scale enterprise funding, needs fulfill for funding basic social, institutional strengthening of woman activity, support poor households alleviation and create the employment. The objectives of this study were, to identify existing problems, to analyze strengths, weakness, opportunities and threats (SWOT) in the savings and borrowing activities from SPP groups and to improve strategies in the Project Management Unit (UPK) of Semparuk sub-district Sambas regency. The primary data were collected to fund user by observation and interviewed techniques, and secondary data obtained from literature studied. Interviews were conducted to 50 respondents whose used credit for three consecutive years and four program actors. The data explained descriptively and assessment strategies analyzed using internal factor evaluation matrix, external factor evaluation matrix, internal-external (IE) matrix, SWOT matrix and quantitative strategic planning matrix. The results show that identified problems were: poor households' economic empowerment had not done yet, group members' savings fail to grow, credit disbursement process was relatively slow, program actors' role fail to facilitate the groups particularly in members' businesses development. Several alternative strategies that can be implemented by District Management Unit (UPK) are: improve the services, expanse the credit markets and marketing networking, maximize the program actors' role, maintain the commitment to developing the SPP, increase the programs promotion, increase the assistance to SPP groups and diversification of deposit and loan products.

Key words: women's savings and loan, empowerment, project management unit

\footnotetext{
$\left.{ }^{\star}\right)$ Korespondensi:

Jl. Raya Sejangkung Komplek Pendidikan Sambas; e-mail: hamdi_h@rocketmail.com
} 


\section{PENDAHULUAN}

Usaha mikro dan kecil merupakan usaha yang paling banyak digeluti di Indonesia. Usaha ini terbukti mampu menopang perekonomian rumah tangga miskin dan bisa menjadi penyangga ekonomi nasional. Perkembangan usaha mikro, kecil dan menengah (UMKM) dan koperasi memiliki potensi yang besar dalam meningkatkan taraf hidup rakyat banyak. Produk Domestik Bruto (PDB) Indonesia Tahun 2007 tumbuh sebesar $6,3 \%$ terhadap Tahun 2006. Bila dirinci menurut skala usaha, pertumbuhan PDB Usaha Kecil dan Menengah (UKM) mencapai 6,4\% dan Usaha Besar (UB) tumbuh 6,2\%. Dibandingkan Tahun 2006 pertumbuhan PDB UKM hanya 5,7\%, dan PDB UB hanya $5,2 \%$. Pada Tahun 2007 total nilai PDB Indonesia mencapai Rp3.957,4 triliun, dimana UKM memberikan kontribusi 2.121,3 triliun rupiah atau 53,6\% dari total PDB Indonesia. Pertumbuhan PDB UKM Tahun 2007 terjadi di semua sektor ekonomi. Jumlah populasi UKM pada tahun 2007 mencapai 49,8 juta unit usaha, atau $99,99 \%$ terhadap total unit usaha di Indonesia, sementara jumlah tenaga kerjanya mencapai 91,8 juta orang atau $97,3 \%$ terhadap seluruh tenaga kerja Indonesia (BPS dan Kemenegkop UKM, 2008).

Besarnya peran UKM harus diikuti dengan adanya pembinaan kepada berbagai kelemahan dan permasalahan yang dihadapinya. Salah satu permasalahan yang dihadapi UKM adalah terbatasnya akses UKM kepada sumber daya produktif. Akses kepada sumber daya produktif terutama terhadap permodalan, teknologi, informasi dan pasar. Jika dilihat dari kenyataan perkreditan nasional dalam hal pendanaan, produk jasa lembaga keuangan sebagian besar masih berupa kredit modal kerja, sedangkan untuk kredit investasi sangat terbatas. Bagi UKM keadaan ini sulit untuk meningkatkan kapasitas usaha ataupun mengembangkan produk-produk yang bersaing. Di samping persyaratan pinjamannya juga tidak mudah dipenuhi, seperti jumlah jaminan meskipun usahanya layak, maka dunia perbankan yang merupakan sumber pendanaan terbesar masih memandang UKM sebagai kegiatan yang beresiko tinggi. Pada tahun 2003, untuk skala pinjaman dari perbankan sampai dengan jumlah 50 juta rupiah, terserap hanya sekitar $24 \%$ ke sektor produktif, selebihnya terserap ke sektor konsumtif (Bappenas, 2008).

Kegiatan Simpan Pinjam khusus Perempuan (SPP) Program Nasional Pemberdayaan Masyarakat Mandiri Pedesaan (PNPM-MPd) merupakan salah satu alternatif pemecahan permasalahan permodalan, bahkan sampai pada bantuan teknis, informasi, teknologi, manajemen, dan pasar. Kegiatan SPP mendapatkan alokasi dana maksimal 25\% dari total dana Bantuan Langsung Masyarakat (BLM) dalam PNPM-MPd. Pada Tahun 2008 yang merupakan tahun pertama dilaksanakannya program PNPM-MPd di
Kecamatan Semparuk, dana SPP teralokasi sebesar 625 juta rupiah tidak terserap habis. Dana yang terserap hanya 484 juta rupiah (setelah ditambah 5\% untuk Unit Pengelola Kegiatan (UPK) dan Tim Pelaksana Kegiatan (TPK) menjadi Rp509.473.680) dengan konsekuensi sisanya (Rp115.526.320) dijadikan dana untuk kegiatan sarana prasarana fisik yang habis terpakai. Untuk alokasi dana Tahun 2009, SPP mendapatkan alokasi 500 juta rupiah terserap habis 475 juta rupiah untuk kelompok reguler. Begitu juga dengan alokasi dana tahun 2010, alokasi dana SPP sebesar 562,5 juta rupiah (termasuk 5\% untuk operasional) terserap habis (UPK Kecamatan Semparuk, 2010).

Jika dilihat dari dana yang mengendap setelah cicilan berjalan, maka dana tersebut banyak yang mengendap, bahkan dari bulan pertama cicilan pengembalian simpanan oleh kelompok SPP. Hal ini terjadi setiap tahun meskipun jumlah dana pinjaman dan peminjam bertambah untuk kelompok reguler maupun kelompok perguliran. Dana mengendap di bulan kedua dan seterusnya sampai setahun lamanya. Jumlah kelompok reguler Tahun Anggaran 2010 sebanyak 17 kelompok dengan jumlah pinjaman Rp534,4 juta dan pinjaman untuk 27 kelompok perguliran Rp1.547.462.000 tanpa daftar tunggu (UPK Kecamatan Semparuk, 2011a).

Dana yang tidak terserap habis secara kontinyu untuk kegiatan SPP menjadi hal yang disayangkan karena tidak bisa digulirkan di masyarakat sehingga secara manfaat akan berkurang. Dilihat dari laporan bulan Mei 2011, kas yang mengendap di rekening bank dan kas UPK Semparuk sebesar Rp637.971.455,85, sedangkan tunggakan sebesar Rp5.884.500. Surplus ditahan sebesar Rp265.588.489,95 dengan surplus berjalan sebesar Rp107.379.472,46 dan saldo pinjaman beredar Rp1.304.293.000 (UPK Kecamatan Semparuk, 2011b). Untuk itu perlu ada usaha memaksimalkan pemanfaatan dana SPP ini bagi kelompok masyarakat miskin. Selain itu, perlu juga dilihat apakah pembinaan terhadap kelompok SPP sudah berjalan dengan baik atau belum. Pembinaan tidak hanya terhadap penyusunan laporan keuangan kelompok, tetapi lebih diarahkan untuk bisa meningkatkan omset, aset, ataupun laba usaha dari setiap anggota serta bagaimana sebaiknya mengelola keuangan keluarga anggota kelompok.

Agar tujuan pelaksanaan program PNPMMPd bisa tercapai, maka dirancang strategi yang tepat berdasarkan kenyataan yang ada pada lembaga UPK, kelompok SPP, dan lingkungan yang berpengaruh bagi kegiatan SPP tersebut, sehingga peningkatan kesejahteraan masyarakat miskin benar-benar bisa terwujud. Berdasarkan pemikiran di atas, maka dilakukan kajian tentang kegiatan SPP di UPK Kecamatan Semparuk Kabupaten Sambas.

Tujuan kajian (1) Mengidentifikasi masalahmasalah yang timbul pada kegiatan SPP 
Kecamatan Semparuk; (2) Mengevaluasi dan menganalisis kekuatan, kelemahan, peluang dan ancaman agar dapat meningkatkan keberhasilan kegiatan kelompok SPP secara maksimal; dan (3) Menyusun strategi perbaikan kegiatan SPP dari program pemberdayaan yang dilaksanakan oleh UPK Kecamatan Semparuk agar bisa mencapai tujuan program.

\section{METODOLOGI}

Kajian dilaksanakan di Kecamatan Semparuk Kabupaten Sambas Kalimantan Barat. Lembaga yang menjadi subyek kajian ialah UPK Kecamatan Semparuk yang merupakan organisasi pelaksana kegiatan PNPM-MPd. Responden kelompok simpan pinjam perempuan berasal dari lima desa, yaitu Desa Semparuk, Singaraya, Sepadu, Sepinggan dan Seburing sesuai dengan kelompok yang menjadi pemanfaat dana program untuk SPP.

Dalam menganalisis dan membahas masalah pada kajian ini dibutuhkan data yang terdiri dari dua sumber data, yaitu:

1. Data sekunder, merupakan data pendukung yang diperoleh melalui studi kepustakaan dan data organisasi, antara lain jurnal penelitian, buletin, tesis, buku, Petunjuk Teknis Operasional (PTO) PNPM-MPd, laporan-laporan hasil kegiatan program, serta data kegiatan SPP reguler dan perguliran dana SPP.

2. Data primer, merupakan data utama yang diperoleh langsung dari lapangan. Pengambilan data menggunakan kuesioner, dengan teknik pengumpulan data sebagai berikut:

a. Wawancara terstruktur, dilakukan untuk mendapatkan data primer langsung dari pelaku usaha mikro (anggota kelompok SPP), yakni kepada 50 responden terpilih dan empat orang pelaku program yang terdiri dari satu orang fasilitator kecamatan, satu orang pendamping lokal, dan dua orang pengurus UPK. Penentuan responden dilakukan secara purposive, dengan pertimbangan kesediaan para anggota kelompok dan pengurus UPK untuk diwawancarai.

b. Observasi, digunakan untuk melakukan pencatatan secara teliti dan sistematik terhadap obyek kajian yang langsung diamati di lapangan guna melengkapi teknik wawancara.

Riset ini dilakukan dengan metode studi kasus yang menghendaki suatu kajian yang rinci, mendalam, menyeluruh atas obyek tertentu, termasuk lingkungannya. Peneliti, bersama-sama dengan pengambil keputusan manajemen, berusaha menemukan hubungan faktor-faktor yang dominan atas permasalahan risetnya. Selain itu, periset dapat menemukan hubungan-hubungan yang tadinya tidak direncanakan, atau terpikirkan.
Keunggulan metode studi kasus antara lain adalah bahwa hasilnya dapat mendukung studistudi yang lebih besar di kemudian hari, dapat memberikan hipotesis-hipotesis untuk riset lanjutan (Umar, 2002).

1. Analisis Statistik Deskriptif

Analisis dilakukan dengan mendeskripsikan, atau menggambarkan data yang telah terkumpul sebagaimana adanya tanpa bermaksud membuat simpulan yang berlaku untuk umum atau generalisasi. Data yang telah diperoleh, baik primer maupun sekunder diolah secara statistik deskriptif dengan pendekatan kuantitatif dalam bentuk frekuensi, persentase, rataan skor, dan tabulasi silang. Kajian strategi disusun dengan tahapan analisis menggunakan matriks Internal Factor Evaluation (IFE), External Factor Evaluation (EFE), InternalExternal (IE), Strengths, Weaknesses, Opportunities, Threats (SWOT), dan Quantitative Strategic Planning Matrix (QSPM) sebagai alat untuk mengevaluasi kinerja pemberdayaan dalam memisahkan masalah-masalah utama yang dihadapi UPK melalui analisis internal dan eksternal.

2. Analisis SWOT Kasus Unit Bisnis

Analisis kasus secara keseluruhan dapat dirumuskan sebagai berikut: memahami situasi dan informasi yang ada, memahami permasalahan yang terjadi, menciptakan berbagai alternatif dan memberikan berbagai alternatif pemecahan masalah, evaluasi pilihan alternatif dan pilih alternatif yang terbaik. Cara yang dapat digunakan untuk memahami masalah yang ada, antara lain harus mengetahui tujuan organisasi, deskripsi mengenai bisnis (produk, harga, keahlian manajemen, kondisi persaingan, dan pesaing di bisnis yang sama), deskripsi mengenai organisasi, dan evaluasi secara keseluruhan (kekuatan, kelemahan, peluang dan ancaman). Selain itu, misi, strategi, tujuan serta semua permasalahan yang dihadapi perusahaan juga dievaluasi. Terkadang masalah yang dihadapi dalam membuat analisis adalah strategi telah berubah, manajemen sangat lemah, struktur organisasi sudah tidak sesuai, perencanaan yang sangat tidak efektif, dan sebagainya. Isu yang berkaitan dengan semua permasalahan di atas perlu dirumuskan mengingat setiap saat lingkungan berubah. Dengan demikian, pengenalan terhadap pasar baru dan peluang pemasaran diperlukan. Selain itu, pemahaman mengenai perubahan internal perusahaan, seperti perubahan teknologi, perubahan produk, dan perubahan struktur biaya, juga diperlukan. Tahap akhir analisis kasus adalah memformulasikan keputusan yang diambil. Keputusannya didasarkan atas justifikasi yang dibuat secara kualitatif maupun kuantitatif, terstruktur maupun tidak terstruktur, dan dengan menggunakan model yang tercanggih maupun tradisional (Rangkuti, 2010). 
Penilaian internal ditujukan untuk mengukur kekuatan dan kelemahan yang dimiliki oleh UPK menggunakan matriks IFE. Sementara untuk mengevaluasi faktor-faktor eksternal UPK/perusahaan yang menyangkut persoalan ekonomi, sosial, budaya, demografi, lingkungan, politik, pemerintahan, hukum, teknologi dan persaingan di pasar industri, di mana perusahaan berada digunakan matriks EFE (Umar, 2002).

\section{HASIL DAN PEMBAHASAN}

Pelaksanaan PNPM-MPd telah mempercepat kemajuan pembangunan Kabupaten Sambas. Program ini mampu menggerakkan partisipasi pemerintah daerah dan pemberdayaan masyarakat selama sembilan tahun sejak Tahun 2003.

\section{Perkembangan kelompok pemanfaat dana}

Sejak pertama dilaksanakannya PNPMMPd di Kecamatan Semparuk, sudah terbentuk kelompok-kelompok yang dulunya mereka berasal dari kelompok pengajian, arisan, dan kelompok pemberdayaan kesejahteraan dan keluarga (PKK). Selama tiga tahun berjalan, sudah tumbuh secara signifikan kelompok-kelompok ekonomi yang beranggotakan perempuan di masyarakat. UPK Kecamatan Semparuk di tahun pertama mengelola dana BLM program Rp2,5 milyar. Dana yang disalurkan untuk kegiatan SPP dimanfaatkan peminjam sebanyak 20 kelompok (141 orang).

Pada tahun ketiga, dana SPP kelompok reguler disalurkan kepada kelompok reguler dengan peminjam sebanyak 17 kelompok (82 orang). Di tahun yang sama, jumlah dana perguliran sebanyak Rp1.536 milyar dengan jumlah peminjam sebanyak 27 kelompok (198 orang). Dari data tersebut, jelas terjadi perkembangan jumlah kelompok SPP (120\%) dan anggota masyarakat yang bisa memanfaatkan dana SPP (196\%). Berdasarkan penilaian UPK, sebanyak 18 kelompok tergolong kelompok pemula, 24 kelompok tergolong kelompok berkembang, dan sebanyak dua kelompok tergolong kelompok siap/matang. Perkembangan kelompok SPP Kecamatan Semparuk secara rinci termasuk penambahan dan pengurangannya tersaji pada Tabel 1.
Dari Tabel 1 terlihat adanya pengurangan jumlah kelompok yang meminjam cukup banyak di Desa Semparuk dan Sepinggan di Tahun 2010 walaupun disertai penambahan kelompok baru. Adanya kelompok yang bubar dan menyebabkan pindahnya anggota-anggotanya ke kelompok lain menunjukkan pembentukan kelompok tidak matang. Disebabkan hanya karena ketua kelompok/pengurus lainnya tidak meminjam, kelompok SPP tersebut tidak meminjam lagi dan kelompok menjadi bubar. Hal ini disebabkan pendampingan yang masih kurang terhadap kelompok SPP, selain faktor internal kelompok itu sendiri. Kelemahan seperti ini jangan sampai menjadi ancaman hilangnya kelompok-kelompok lain di waktu yang akan datang yang sementara ini masih aktif. Selain itu, lemahnya kelembagaan dan organisasi berbasis masyarakat akan tercermin dari kemampuan lembaga dan organisasi dalam menyalurkan aspirasi anggota kelompoknya untuk perencanaan kegiatan usaha, serta dalam memperkuat posisi tawar dalam masyarakat (Dasaluti, T., A.V.S. Hubeis, dan E.S. Wiyono, 2010).

\section{Perguliran dana simpan pinjam}

Dana yang dipinjamkan kepada kelompok SPP terdiri dari dua macam, yaitu dana reguler dan dana perguliran. Dana reguler adalah dana yang didapat dari BLM untuk tahun berjalan, dan setelah pengembaliannya dana tersebut masuk menjadi dana perguliran untuk dipinjamkan kepada kelompok perguliran. Dana perguliran menjadi dana abadi masyarakat. Perguliran dana SPP di Kecamatan Semparuk dari Tahun 2009 sampai Tahun 2010 cukup baik, walaupun ada tunggakan Rp5.126.500 (0,33\% dari modal).

Secara kinerja usaha, saat ini kegiatan SPP berjalan cukup baik. Surplus ditahan yang didapatkan dari tahun pertama sampai akhir Tahun 2010 sejumlah Rp265.588.489,95, sedangkan surplus berjalan sampai Mei 2011 sejumlah Rp107.379.172,46. Angka pengembalian pinjaman juga tinggi, yaitu 99,67\%. Angka ini lebih tinggi dibandingkan rataan pengembalian tingkat Provinsi Kalimantan Barat (91\%) dan nasional (94\%). Apalagi angka tunggakan 0,33\% tersebut masih dalam masa penjadwalan ulang (reschedule) yang diyakini bisa ditagih. Keuntungan

Tabel 1. Perkembangan kelompok SPP Kecamatan Semparuk

\begin{tabular}{lcrrrr}
\hline Lokasi (desa) & \multicolumn{2}{c}{ Jumlah kelompok yang dilayani (orang) } & $\begin{array}{c}\text { Peningkatan } \\
\text { kelompok yang } \\
\text { dilayani (orang) }\end{array}$ & $\begin{array}{c}\text { Pertumbuhan } \\
\text { jumlah kelompok } \\
(\%)\end{array}$ \\
\cline { 2 - 5 } & $2008 / 2009$ & $2009 / 2010$ & $2010 / 2011$ & 10 & 125,00 \\
\hline Semparuk & 8 & $8+12-1=19$ & $19+6-7=18$ & 9 & 225,00 \\
Singaraya & 4 & $4+5-0=9$ & $9+4-0=13$ & 1 & 33,00 \\
Sepinggan & 3 & $3+3-0=6$ & $6+1-3=4$ & 3 & 100,00 \\
Seburing & 3 & $3+1-0=4$ & $4+3-1=6$ & 1 & 50,00 \\
Sepadu & 2 & $2+0-0=2$ & $2+1-0=3$ & 24 & 120,00 \\
\hline TOTAL & 20 & $20+21-1=40$ & $40+15-11=44$ & & \\
\hline
\end{tabular}

Sumber: UPK Kecamatan Semparuk, 2011b. 
yang didapat oleh UPK dari jasa pinjaman $(1,50 \%$ per bulan pada Tahun 2008-2009 dan 1,25\% perbulan mulai Tahun 2010) digunakan untuk operasional UPK (maksimal 75\%, dan dialokasikan hanya Rp60 juta di Tahun 2010/2011), bantuan sosial masyarakat miskin (dianggarkan Rp32.241.250), dan untuk pengembangan kelembagaan dialokasikan dana Rp18.959.500 (UPK Kecamatan Semparuk, 2011b). Dari anggaran pengeluaran tersebut masih lebih besar untuk penambahan modal.

Dari perkembangan kelompok dan peningkatan laba usaha, dimungkinkan aset UPK akan terus meningkat di masa mendatang jika dikelola dengan lebih baik lagi. Berkembang dan besarnya angka pengembalian kredit merupakan akibat dari pelaksanaan tanggung renteng yang berjalan baik di kelompok dan kontrol yang kuat dari masyarakat luas.

\section{Sumber informasi pertama dana SPP}

Anggota kelompok SPP mayoritas (48\%) mendapatkan penjelasan langsung pada pertemuan-pertemuan PNPM-MPd dari FK/FT dan PL. Selebihnya mendapatkan dari pelaku program lainnya yaitu Kader Pemberdayaan Masyarakat Desa (KPMD), TPK, UPK, Badan Pengawas (BP) UPK, kelompok arisan, aparat desa, keluarga, dan lainnya (teman/tetangga). Sumber informasi pertama tentang adanya pinjaman dana SPP dari PNPM-MPd yang didapatkan secara rinci sebagaimana terlihat pada Gambar 1.

Dari Gambar 1 bisa disimpulkan bahwa peran pertemuan yang diadakan oleh PNPM-MPd efektif untuk memberikan informasi kepada masyarakat. Begitu pula dengan peran pelaku program dan kelompok arisan. Peluang untuk perluasan pasar adalah pemberian informasi kepada kelompok-kelompok pengajian dan meningkatkan peran aparat desa dalam menginformasikan kegiatan SPP kepada masyarakat.

\section{Sasaran Kegiatan SPP}

Kegiatan SPP bertujuan untuk mengembangkan potensi kegiatan simpan pinjam perdesaan, kemudahan akses pendanaan usaha skala mikro, pemenuhan kebutuhan pendanaan sosial dasar, dan memperkuat kelembagaan kegiatan kaum perempuan serta mendorong pengurangan Rumah Tangga Miskin (RTM) dan penciptaan lapangan kerja. Dilihat dari pencapaian tujuan kegiatan SPP untuk pengurangan RTM, maka tujuan ini tidak tercapai, atau jika tercapai angkanya hanya kecil. Dari penerima manfaat dana SPP yang ada, terlihat hanya keluarga yang rawan miskin saja, atau keluarga mampu yang ikut terbantu dari mengikuti dan memanfaatkan dana kegiatan SPP.

Sebenarnya UPK merupakan lembaga kredit mikro yang potensial untuk dikembangkan dalam rangka pengurangan keluarga RTM. Berdasarkan data di UPK Kecamatan Semparuk, $66,83 \%$ dari peminjam dana perguliran dan $85,98 \%$ peminjam dana reguler berasal dari RTM. Secara total peminjam dana SPP Tahun 2010 yang berasal dari masyarakat miskin 73,46\% (UPK Kecamatan Semparuk, 2010). Akan tetapi jika dilihat dari keadaan rumah tangga peminjam di lapangan, tidak tergolong kalangan termiskin di desanya.

Fasilitasi PNPM-MPd yang dilaksanakan pelaku program pada RTM perlu diperbaiki. Ini untuk memastikan efektif tidaknya sasaran penerima manfaat dana SPP. Secara umum, pada tataran implementasi di lapangan, dana SPP dipahami sebagai dana pinjaman bagi yang diutamakan, yaitu mereka yang sudah memiliki usaha sudah berjalan untuk penambahan modal dan berasal dari RTM. Meskipun demikian, kelompok SPP yang terbentuk memahami bahwa peminjam boleh saja berasal dari keluarga nonRTM dan PNPM bukanlah program secara eksklusif hanya untuk kelompok miskin, dengan kata lain yang penting dalam kelompok peminjam tersebut harus tetap ada yang berasal dari RTM. Pemahaman tersebut membuat kegiatan SPP seperti lebih menekankan pada aspek kelancaran pengembalian kredit dibandingkan aspek pemberdayaan, atau hanya mencari aman (safety) dalam pengelolaan keuangan.

Akibat dari pemahaman masyarakat dan sebagian Pelaku tentang dana SPP yang dijelaskan sebelumnya, program ini dapat diberikan kepada pihak-pihak di luar RTM, maka anggota kelompok inilah yang mempunyai potensi pengembalian kredit secara lancar, bukan

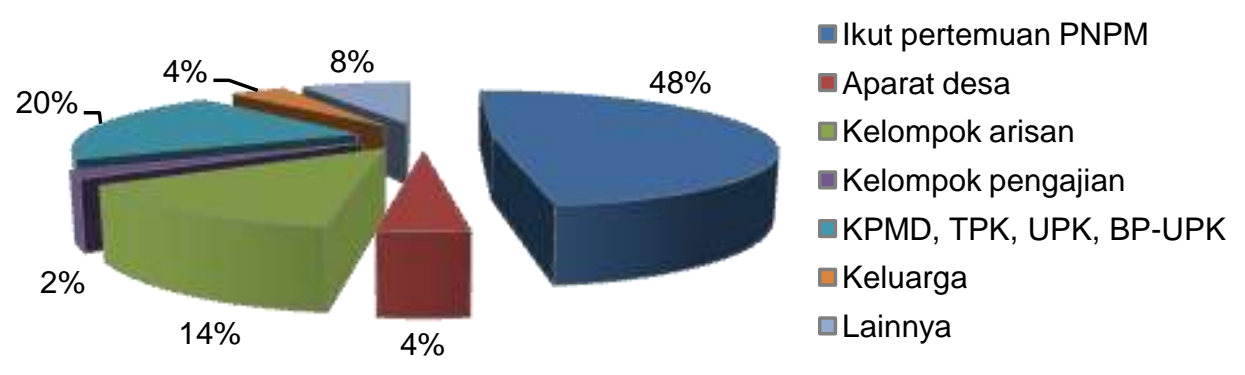

Gambar 1. Sumber informasi pertama dana SPP 
kelompok miskin, atau termiskin. Namun penelitian Khandker (2000) menyatakan bahwa angka pengembalian pinjaman orang miskin lebih tinggi dibandingkan bukan orang miskin. Berdasarkan observasi lapangan dari sisi sasaran penerima manfaat, SPP bukanlah program yang bertujuan untuk menanggulangi kemiskinan, kecuali sedikit. Hal ini dikarenakan mayoritas perempuan yang memanfaatkan dana SPP tersebut bukan dari kelompok miskin dan termiskin di desanya, meskipun dalam proposal perguliran yang diajukan, jumlah RTM-nya lebih banyak. Selain itu pula, dari kelompok SPP yang diwawancarai, hanya ada $20 \%$ yang membuka usaha baru dari dana yang didapatkan dari SPP.

Aspek prioritas peminjaman bagi yang bisa lancar dalam pengembalian pinjaman berakibat pada banyaknya kelompok RTM yang tidak berani meminjam, atau bingung harus diusahakan untuk apa dana tersebut jika meminjam. Banyak orang di desa yang tidak ingin bergabung ke dalam kelompok (meskipun diberi kesempatan) untuk meminjam, karena takut tidak dapat mengembalikan kredit yang diberikan padanya. Dalam hal ini, belum ada pemberdayaan yang sungguh-sungguh untuk menyadarkan akan potensi diri dan membaca peluang usaha yang dapat dijalankan. Apalagi sekarang sudah ada aturan yang mempermudah pelaku usahatani untuk bisa memanfaatkan dana SPP, yaitu mencicil minimal tiga kali dalam setahun. Aturan tersebut membuka peluang usaha yang perputaran uangnya lambat atau didapat setelah panen.

Para pelaku program belum melaksanakan pemberdayaan sampai ke arah yang seharusnya sesuai dengan tahapan pemberdayaan. Kondisi ini diperparah lagi oleh adanya penekanan persyaratan yang cukup memberatkan bagi RTM yang dilaksanakan Tahun 2011 dan akan lebih menutup kemungkinan bagi RTM untuk meminjam. Syarat tersebut adalah barang agunan anggota ke kelompoknya yang bisa diuangkan di kemudian hari, meskipun tidak menyerahkan surat-menyuratnya. Adanya syarat tersebut sungguh membuat orang miskin perdesaan semakin takut untuk meminjam. Apalagi sudah ada contoh di lapangan ada anggota kelompok SPP yang tidak bisa melunasi pembayaran kredit, harus menggadaikan tanah yang dimiliki untuk pelunasan utangnya kepada UPK.

\section{Profil Kelompok Simpan Pinjam}

\section{Karakteristik kelompok simpan pinjam}

Pemanfaat dana merata pada kelompok usia dari 30-53 tahun. Ini berarti perempuan di bawah usia 30 tahun belum tergarap, padahal banyak pada usia tersebut yang sudah menikah dan memerlukan pembinaan ekonomi rumah tangga. Dari sisi pendidikan, penyebaran pemanfaat dana terlihat wajar sesuai dengan komposisi penduduk yang mayoritas berpendidikan dasar. Sama halnya dengan penelitian Arnaya dan
Utama (2012), tingkat pendidikan penerima bantuan SPP didominasi oleh mereka yang berpendidikan SD $(52,27 \%)$. Lama usaha pemanfaat dana SPP $80 \%$ sudah berjalan sebelum mendapatkan pinjaman dana SPP, sehingga bisa diartikan pinjaman SPP diberikan kepada usaha yang sudah berjalan, bukan dimanfaatkan RTM yang tidak punya usaha selain bertani. Apalagi ini juga didukung oleh pengalaman usaha yang dimiliki. Usaha baru yang diciptakan anggota kelompok SPP setelah mendapatkan bantuan/ pinjaman dana SPP $20 \%$ (kelompok lama berusaha lebih dari dua sampai dengan tiga tahun). Kelancaran pengembalian pinjaman menjadi hal yang biasa karena pinjaman diberikan kepada usaha yang sudah lama berjalan, ditambah lagi kewajiban tanggung renteng di setiap kelompok yang berjalan efektif. Lokasi dan status tempat usaha mayoritas di luar lokasi pasar dengan usaha tetap-milik sendiri.

Pada semua rentang kredit didominasi oleh peminjam yang mengusahakan dana pinjamannya untuk usaha perdagangan. Urutan kedua terbesar peminjamnya dari usaha jasa. Dari dua usaha tersebut dimengerti memiliki perputaran uang yang cepat, sehingga peminjam dapat mengembalikan pinjaman dengan tepat waktu. Hal ini didukung pula oleh usaha yang dijalankan sudah lama, sehingga diketahui kemampuan membayarnya. Kekuatan UPK di sini adalah pembayaran yang lancar dari kelompok SPP dan pelaksanaan tanggung renteng yang efektif.

\section{Besaran kredit pada setiap bidang usaha}

Besaran kredit yang didapatkan anggota kelompok berbeda-beda sesuai kebutuhan dan kemampuan membayar. Berdasarkan Gambar 2, besaran kredit mayoritas pada rentang 8-13 juta pada bidang perdagangan dan jasa. Bidang ini dibiayai lebih disebabkan potensi pembayaran kredit yang lancar karena usahanya memiliki perputaran uang yang cepat. Besaran kredit pada masing-masing bidang usaha seperti terlihat pada Gambar 2.

Usaha yang mendapatkan pendanaan merupaka usaha pada skala mikro. Usaha yang bisa terus dikembangkan melihat potensi sumber daya lokal, keterampilan RTM, permodalan yang memungkinkan, dan pemasaran produk adalah peternakan dan hortikultura.

\section{Manfaat peningkatan pendapatan ekonomi rumah tangga}

Anggota kelompok SPP yang sudah memanfaatkan dana SPP mendapatkan peningkatan pendapatan. Peningkatan pendapatan mayoritas (70\%) berada pada rentang Rp250.000Rp1.350.000 per bulan. Secara umum, Gambar 3 menunjukkan bahwa mayoritas setiap besaran pinjaman meningkatkan pendapatan pada rentang Rp2-7 juta dan Rp8-13 juta. Peningkatan pendapatan juga tidak selalu berbanding lurus dengan besarnya pinjaman. Kinerja pinjaman dengan 
kisaran Rp2.7 juta bisa meningkatkan rataan pendapatan paling tinggi, yaitu $20 \%$, sedangkan pinjaman terbesar Rp38-43 juta hanya mampu meningkatkan rataan pendapatan $10 \%$.

\section{Persaingan dengan lembaga keuangan lain}

Sebagian kecil pemanfaat dana SPP (22\%) pernah mendapatkan pembiayaan dari bank dan Koperasi, dengan mayoritas (78\%) tidak pernah mendapatkan bantuan permodalan dari lembaga manapun sebelumnya. Alasan memilih meminjam dana SPP adalah karena di UPK tidak menggunakan agunan dan persyaratannya bisa dipenuhi. Dari data tersebut, dapat diartikan bahwa meskipun di perdesaan, lembaga keuangan bank dan bukan bank juga memiliki pasar kredit. Lembaga itu merupakan pesaing bagi UPK dalam pinjaman untuk usaha mikro dan kecil. Bank yang menjadi ancaman bagi bisnis di bidang pembiayaan mikro (microfinance), antara lain Bank Rakyat Indonesia (BRI) dan Bank Pembangunan Daerah (BPD) yang berkantor unit dengan jarak 150 m dengan kantor UPK.
Lembaga keuangan non-bank yang menjadi pesaing adalah koperasi dan Credit Union (CU). CU sudah beroperasi di Kecamatan yang bersebelahan dengan Kecamatan Semparuk. Ini akan menjadi sebuah ancaman bagi UPK jika masih diterapkannya kebijakan yang memperlambat proses pencairan kredit. Hal ini bertolak belakang dengan kebijakan kredit di CU yang proses pencairannya lebih cepat dengan tingkat suku bunga yang bersaing, termasuk bunga yang lebih kompetitif bagi tabungan nasabahnya dibandingkan bank.

\section{Perubahan paradigma berpikir}

Bagi sebagian besar (96\%) pemanfaat dana SPP, besar angsuran tidak memberatkan. Latar belakang anggota kelompok SPP yang banyak berasal dari kelompok arisan/pengajian, mayoritas (80\%) memiliki tabungan, sehingga rutin menabung di kelompok saat kegiatan SPP diikutinya tanpa merasa terbebani. Mayoritas pemanfaat dana SPP juga terus menabung di kelompok meskipun sudah tidak memiliki kewajiban pengembalian pinjaman. Dengan adanya

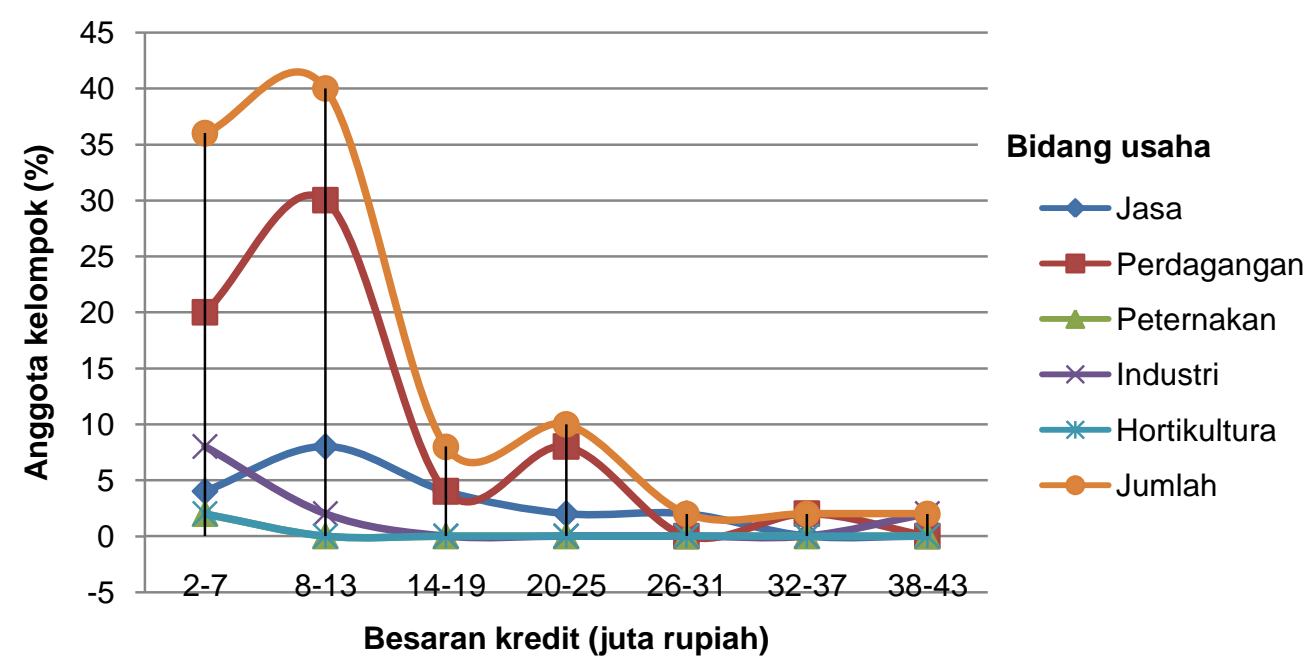

Gambar 2. Besaran kredit pada bidang-bidang usaha anggota

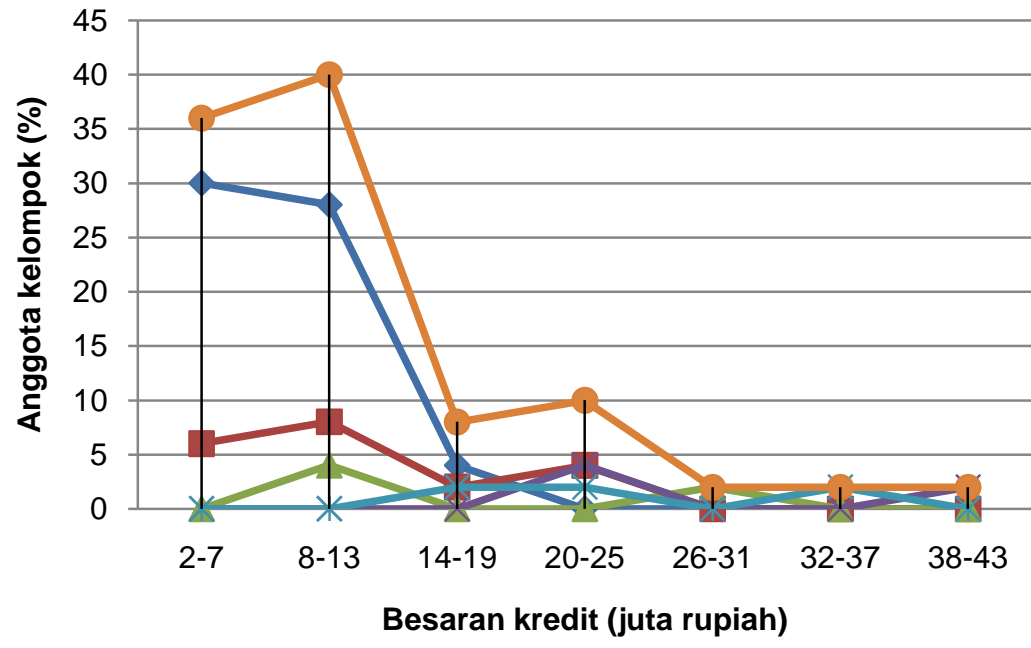

Gambar 3. Peningkatan pendapatan anggota
Peningkatan pendapatan (ribu Rp/bulan)

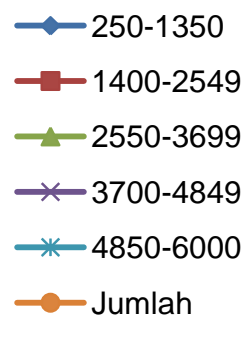


kegiatan SPP, pemanfaat dana terbiasa membuat perencanaan keuangan keluarga dan merasa terbantu dalam memajukan usahanya. Hal ini didukung pula dengan pelayanan yang memuaskan dari UPK, sehingga anggota kelompok berharap agar kegiatan SPP terus digalakkan. Secara rinci, perubahan paradigma berpikir anggota SPP ini tertera pada Tabel 2.

Para pemanfaat dana merasa terbantu dengan adanya kegiatan SPP. Menurut mereka, semua berdampak positif baik dari sisi paradigma berpikir maupun dari sisi kebiasaan yang mengikutinya. Apalagi adanya pelayanan yang baik dari UPK. Dari observasi yang dilakukan, pengurus UPK sering melayani kelompok SPP di luar kantor, baik di rumahnya maupun menjemput ke rumah anggota kelompok SPP.

\section{Persepsi terhadap pinjaman dana SPP}

Anggota kelompok SPP mau meminjam karena tidak mengalami kesulitan dalam mendapatkan kredit UPK (86\%), persyaratan pengajuannya ringan (100\%), prosesnya mudah (56\%), walaupun sebagian besar (36\%) mengakui bahwa proses pencairan kreditnya lama. Pinjaman dana SPP dimanfaatkan untuk meningkatkan usaha $(70 \%)$ sehingga omset dan keuntungannya meningkat dari sebelumnya (100\%). Tujuan utama menabung di kelompok adalah sebagai cadangan untuk membayar angsuran jika belum ada uang untuk mencicil (64\%). Persepsi responden secara rinci tersaji pada Tabel 3.

Pemanfaat dana sangat ingin adanya perubahan yang positif pada realisasi kredit. Proses realisasi kredit yang lama disebabkan adanya penundaan pencairan sampai terselesaikannya pembayaran dari kelompok lain dari desa yang sama. Selain itu, proses verifikasi yang tidak direncanakan dengan baik selama ini juga memperlambat proses terutama untuk kelompok perguliran. Verifikasi untuk kelompok perguliran perlu lebih teliti dan terencana dengan baik. Tim Verifikasi (TV) yang selama ini selalu berubahubah personilnya perlu dikaji lagi walaupun tugasnya bersifat ad-hock. Pinjaman dengan jumlah besar dengan jangka waktu yang lebih lama perlu verifikasi yang lebih teliti sebagaimana untuk kelompok perguliran. Selain itu juga bisa mencegah penyalahgunaan dana SPP oleh kelompok ataupun anggotanya. Untuk melaksanakan tugas tersebut, perlu ditangani oleh orangorang yang benar-benar memahami konsepsi program yang lebih menyeluruh agar hasilnya lebih baik. Jadi peran TV perlu dimaksimalkan dalam proses verifikasi.

\section{Kondisi fasilitas kelompok SPP}

Diakui responden, bahwa FK/FT/UPK/PL (36\%) memfasilitasi pembuatan Anggaran Dasar/ Anggaran Rumah Tangga (AD/ART), tetapi tidak memfasilitasi pembuatan Standar Operating Procedure (SOP: 100\%). Sebagian besar anggota mengakui sudah difasilitasi dalam penguatan administrasi dan pelaporan keuangan kelompok (92\%), peningkatan simpanan (100\%), peningkatan kapasitas pengurus dan anggota kelompok (96\%) dan bantuan dalam penguatan pengelolaan keuangan, berupa administrasi dan kelompok SPP mengakui bahwa belum difasilitasi dalam peningkatan permodalan dengan pengembangan jaringan (100\%). Fasilitas kepada kelompok baru sekedar untuk pengamanan modal UPK agar kelompok bisa membayar pinjaman dengan lancar. Upaya pembinaan kelompok diarahkan pada peningkatan kapasitas pengurus dalam mengelola keuangan dan pelaporannya, mengatasi masalah tunggakan dan penguatan administrasi. Upaya pematangan kelompok menuju organisasi yang rapi melalui pembuatan $A D / A R T$ tidak maksimal dan pembuatan SOP belum dilakukan. Untuk perbaikannya, fasilitas harus diperbaiki dengan membina kelompok berdasarkan tingkat kematangannya, sehingga lebih terarah. Selain itu, pembiayaan secara berkelompok sebagaimana yang sudah berjalan di SPP, pelayanan nonfinansial dari lembaga keuangan dan insentif yang dinamis berkontribusi terhadap meningkatnya kinerja pengembalian pinjaman kredit mikro (Godquin, 2004).

Tabel 2. Paradigma berpikir anggota

\begin{tabular}{clrr}
\hline No & \multicolumn{1}{c}{ Keterangan } & Ya (\%) & Tidak (\%) \\
\hline 1 & Besar angsuran ke UPK memberatkan & 4,00 & 96,00 \\
2 & Memiliki tabungan sebelum menjadi anggota & 80,00 & 20,00 \\
3 & Rutin menabung setiap bulan di kelompok & 92,00 & 8,00 \\
4 & Terbebani dengan kewajiban menabung pada kelompok SPP & 10,00 & 90,00 \\
5 & Akan terus menabung walaupun sudah tidak memiliki kewajiban dalam & 56,00 & 44,00 \\
& kelompok SPP & 100,00 & 0,00 \\
6 & Membuat perencanaan anggaran keuangan keluarga setelah menjadi anggota & 100,00 & 0,00 \\
& kelompok SPP & 84,00 & 16,00 \\
7 & Kegiatan SPP menunjang peningkatan/kemajuan usaha secara keseluruhan & 100,00 & 0,00 \\
8 & Pelayanan UPK memuaskan & & \\
9 & Kegiatan SPP harus terus digalakkan & &
\end{tabular}


Tabel 3. Persepsi terhadap pinjaman dana SPP

\begin{tabular}{|c|c|c|c|}
\hline Keterangan & Pilihan jawaban & $\begin{array}{l}\text { Jumlah } \\
\text { (org) }\end{array}$ & $\begin{array}{c}\text { Persentase } \\
(\%)\end{array}$ \\
\hline \multirow{2}{*}{ Sulit mendapatkan kredit } & $\mathrm{Ya}$ & 7 & 14,00 \\
\hline & Tidak & 43 & 86,00 \\
\hline \multirow[t]{3}{*}{ Persyaratan pengajuan kredit } & Ringan & 50 & 100,00 \\
\hline & Sedang & 0 & 0,00 \\
\hline & Berat & 0 & 0,00 \\
\hline \multirow[t]{3}{*}{ Proses mengajukan kredit } & Mudah & 28 & 56,00 \\
\hline & Sedang & 22 & 44,00 \\
\hline & Lama & 0 & 0,00 \\
\hline \multirow{3}{*}{$\begin{array}{l}\text { Realisasi pencairan kredit dana } \\
\text { perguliran }\end{array}$} & Cepat & 17 & 34,00 \\
\hline & Sedang & 15 & 30,00 \\
\hline & Lama & 18 & 36,00 \\
\hline \multirow[t]{3}{*}{ Alasan mengajukan pinjaman } & Ingin mendapatkan modal & 10 & 20,00 \\
\hline & Ingin meningkatkan usaha & 37 & 74,00 \\
\hline & Hanya sekedar ikut-ikutan & 3 & 6,00 \\
\hline \multirow{3}{*}{$\begin{array}{l}\text { Omset usaha dan keuntungan setelah } \\
\text { mendapat pinjaman }\end{array}$} & Meningkat dari sebelumnya & 50 & 100,00 \\
\hline & Sama dg sebelumnya & 0 & 0,00 \\
\hline & Turun dari sebelumnya & 0 & 0,00 \\
\hline \multirow[t]{4}{*}{ Alasan/tujuan menabung di kelompok } & Cadangan membayar angsuran & 32 & 64,00 \\
\hline & Biaya pendidikan anak & 1 & 2,00 \\
\hline & Memenuhi kebutuhan darurat & 6 & 12,00 \\
\hline & Lainnya (dipinjamkan lagi) & 11 & 22,00 \\
\hline
\end{tabular}

\section{Pengelolaan Usaha}

\section{Kondisi fasilitas pengelolaan usaha}

Usaha anggota pemanfaat dana SPP dikelola sama seperti ketika belum bergabung dengan kelompok SPP. Dalam pengelolaan usahanya, belum ada fasilitasi program untuk pengembangan jaringan terutama pemberian informasi mengenai bantuan teknis, misalnya lembaga-lembaga pelatihan, LSM, permodalan, maupun usaha $(100 \%)$. Tidak ada bantuan dalam penguatan pengelolaan usaha melalui pemasaran produk, baik mengenai mutu, jaringan distribusi, strategi promosi, persaingan harga jual dan sebagainya (100\%).

Pengusaha mikro dan kecil pemanfaat dana SPP mengakui bahwa masih belum ada bantuan dalam penguatan pengelolaan usaha produksi, yang mencakup masalah pasokan bahan baku, proses produksi (sistem, kapasitas sarana, dan kapasitas sumber daya manusia/SDM) dan sebagainya (100). Terlihat bahwa fasilitas bagi anggota kelompok belum menyentuh sisi manajemen usaha pemanfaat dana SPP. Keterbatasan fasilitator kecamatan dalam kemampuan untuk penguatan pengelolaan usaha anggota harus diatasi. Jika tidak kredibel, maka program bisa melakukan kerjasama dengan lembaga lain, seperti bekerjasama dengan perguruan tinggi yang memiliki tenaga akademis bidang agribisnis, teknologi industri pertanian, atau manajemen.

\section{Pengelola usaha}

Program PNPM-MPd mengedepankan prinsip kesetaraan dan keadilan gender dengan meningkatkan partisipasi seluruh masyarakat, khususnya masyarakat miskin atau kelompok perempuan. Pelibatan perempuan dilakukan dalam pengambilan keputusan perencanaan, pelaksanaan, pemantauan dan pelestarian pemba- ngunan. Dalam pengelolaan usaha anggota kelompok SPP juga mestinya memperhatikan prinsip di atas.

Dilihat dari usaha yang dikelola, ternyata usahanya mayoritas dikelola oleh perempuan, baik dilakukan sendiri maupun dibantu oleh lakilaki. Positifnya pengelolaan dana oleh perempuan karena jika perempuan yang mengelola usaha, maka keuntungan yang dihasilkan lebih baik (bisa dua kali lebih besar) daripada jika dikelola oleh laki-laki. Sesuai penelitian Suman (2007), bahwa pengelolaan usaha oleh perempuan lebih mampu menghasilkan pendapatan daripada pengelolaan oleh laki-laki. Selain itu, pengelolaan oleh perempuan berdampak positif pada pemanfaatan keuntungan yang didapat untuk meningkatkan konsumsi keluarga terutama pemenuhan gizi keluarga, pendidikan anak-anak dan pengaturan keuangan lain yang lebih terarah. Pendapat in selaras dengan Qoriah dan Sumarti (2008), yang menyatakan bahwa perempuan mampu mengambil keputusan dalam rumah tangga, ketika suami merantau/tidak ada. Hal ini disebabkan tanggung jawab perempuan pada peran domestiknya yang lebih tinggi.

\section{Perempuan pengusaha kecil}

Perempuan pemanfaat dana SPP sebagian (22\%) tergolong pengusaha kecil karena omset usahanya mencapai Rp25 juta per bulan, atau lebih. Usahanya bergerak di jasa kredit barang, penggilingan padi, warung sekaligus kios bensin, agen jeruk, pandai besi dan angkutan sekaligus dagang udang galah. Meskipun belum maksimal, dalam usaha kecil juga dikelola oleh perempuan secara dominan, baik pengambilan keputusan maupun pelaksana teknis.

Usaha yang dikelola langsung (secara dominan) oleh perempuan masih terletak pada area domestik, seperti jasa kredit barang dan 
warung dan kios bensin (begitu juga usaha-usaha mikro). Jasa kredit barang dan warung atau kios bensin bisa dilaksanakan bersamaan dengan pelaksanaan tugas domestik seorang istri, seperti memasak, menata perabot rumah tangga, dan menjaga anak-anak sambil menjaga warung atau kios bensin. Kondisi ini juga memperlihatkan bahwa laki-laki sebagai pencari nafkah utama dan perempuan sebagai pencari nafkah tambahan. Padahal jika dilihat dari kontribusi, perempuan memberikan andil yang besar dalam keluarga.

\section{Kendala dan saran anggota SPP}

Kendala yang dihadapi oleh anggotaanggota SPP, di antaranya pengembalian pinjaman dalam masa satu tahun (12 bulan) dirasa terlalu cepat, sehingga tidak bisa memutar modal dengan leluasa. Kendala lain adalah pengembalian pinjaman yang terlambat dari kelompok lain dari desa yang sama bisa menghambat pencairan dana bagi kelompok, meskipun kelompoknya bagus/lancar pengembaliannya. Selain itu, sebagian kecil terjadi koordinasi yang kurang baik di antara anggota kelompok dengan Ketua. Bahkan ada indikasi untuk menguasai dana pinjaman anggotanya dengan memotong jumlah pinjaman anggota, kemudian dijadikan pinjaman untuk oknum Ketua secara tidak sukarela. Ada juga anggota kelompok yang menghilang/ melarikan diri dari Desa dan tidak tahu pergi ke mana, sehingga pembayarannya tidak lancar dan terpaksa ditanggulangi dari pihak keluarga yang bersangkutan.

Anggota kelompok berharap akan ada perbaikan dalam proses pencairan dana pada tahun berikutnya. Adanya kelompok yang terlambat dalam pelunasan pembayaran pinjaman diharapkan tidak mengganggu pencairan dana kelompok lainnya. Kelompok yang memiliki rekam jejak (track record) pengembalian pinjaman yang baik, diharapkan bisa mendapatkan prioritas dalam pencairan dana, tidak lagi menunggu kelompok lain dalam menyelesaikan tunggakannya. Sebagian besar anggota kelompok SPP berharap jasa pinjaman diturunkan dari 1,25\% per bulan dan adanya tambahan jangka waktu pinjaman dari yang sebelumnya 12 bulan menjadi 18 bulan, terutama bagi peminjam yang sudah lama. Selain itu, adanya persyaratan memasukkan jaminan/ agunan barang juga memberatkan bagi yang tidak mempunyai apa-apa untuk diagunkan. Hal ini dapat menghalangi peminjam dari RTM untuk memanfaatkan dana SPP. Diharapkan syarat agunan ke kelompok dapat dihilangkan, karena akan menghalangi perempuan dari RTM untuk meminjam. Anggota kelompok juga berharap jadwal pengembalian pinjaman diperlunak, terutama jika tanggal jatuh tempo pada hari libur, maka pembayarannya dapat dilakukan pada hari kerja berikutnya dan tetap tidak dianggap terlambat. Hal ini dapat berpengaruh pada penilaian terhadap kelompoknya, apakah berhak, atau tidak untuk mendapatkan insentif.

\section{Perumusan Strategi Perbaikan}

\section{Analisis Matriks IFE}

Analisis matriks IFE dilakukan terhadap lingkungan internal perusahaan, sehingga diperoleh faktor-faktor kunci yang termasuk kekuatan dan kelemahan. Skor yang diperoleh dari matriks ini menunjukkan kemampuan perusahaan dalam memanfaatkan kekuatan dan mengatasi kelemahan yang dimiliki. Faktor yang menjadi kekuatan utama kegiatan SPP Kecamatan Semparuk adalah pelaksanaan tanggung renteng berjalan baik dan adanya pendampingan kepada kelompok. Sementara itu kelemahan utama yang dimiliki adalah simpanan anggota tidak berkembang dan UPK belum memiliki legal lending.

Dari hasil analisis perhitungan faktor-faktor internal, didapatkan total skor 2,597 (Tabel 4). Nilai ini berada di atas rataan 2,5, sehingga menunjukkan posisi internal perusahaan cukup kuat, di mana perusahaan memiliki kemampuan di atas rata-rata dalam memanfaatkan kekuatan dan mengatasi kelemahan internal. Persentase skor kekuatan 74,43\% menunjukkan kemampuan memanfaatkan kekuatan lebih utama untuk dilakukan dibandingkan dengan mengatasi kelemahan $(25,57 \%)$ yang dimiliki.

\section{Analisis Matriks EFE}

Analisis matriks EFE dilakukan terhadap lingkungan eksternal perusahaan, sehingga diperoleh faktor-faktor kunci yang termasuk peluang dan ancaman. Skor yang diperoleh dari matriks ini menunjukkan kemampuan perusahaan dalam memanfaatkan peluang dan mengatasi ancaman yang dimiliki. Hasil analisis matriks EFE terdapat pada Tabel 5. Faktor peluang utama yang dimiliki oleh kepengurusan UPK adalah pasar kredit masih luas di luar perdagangan dan jasa. Selain itu, faktor yang juga mempengaruhi adalah banyak masyarakat miskin belum mengakses dana SPP. Faktor yang menjadi ancaman utama bagi program ini adalah ada kecenderungan ketergantungan terhadap dana SPP dan persaingan dengan lembaga keuangan non-bank.

Dari hasil analisis perhitungan faktor strategi eksternal didapatkan total skor 2,653. Angka ini menunjukkan bahwa perusahaan memiliki kemampuan rataan dalam memanfaatkan peluang yang ada dan mengantisipasi ancaman, dan persentase skor peluang 70,69\% menunjukkan kemampuan dalam memanfaatkan peluang lebih besar dibandingkan dengan pengaruh ancaman $(29,31 \%)$ terhadap kegiatan SPP. Untuk memperbaiki kondisi perusahaan dan menguasai pasar, maka UPK harus memanfaatkan peluang secara maksimal. 
Tabel 4. Matriks IFE kegiatan SPP Kecamatan Semparuk

\begin{tabular}{llrl}
\hline Faktor Internal & Bobot & Rating & Skor \\
\hline Kekuatan & & & \\
A. Prosedur dan syarat pengajuan kredit mudah dan ringan & 0,045 & 3,750 & 0,168 \\
B. Ada pendampingan kepada kelompok & 0,073 & 3,750 & 0,274 \\
C. Pelaksanaan tanggung renteng berjalan baik & 0,072 & 4,000 & 0,288 \\
D. Musyawarah efektif memberikan informasi kepada masyarakat & 0,040 & 3,500 & 0,139 \\
E. Bantuan dana SPP sangat bermanfaat bagi anggota & 0,045 & 3,500 & 0,156 \\
F. UPK memiliki SDM bermutu & 0,058 & 3,250 & 0,190 \\
G. Kontrol yang kuat dari masyarakat luas & 0,065 & 3,500 & 0,229 \\
H. Peran perempuan cukup dominan dalam pengelolaan usaha & 0,036 & 3,000 & 0,109 \\
I. Pemberlakuan reward and punishment & 0,052 & 3,500 & 0,183 \\
J. Pelayanan yang baik dari UPK & 0,056 & 3,500 & 0,197 \\
\hline Subtotal & & & 1,933 \\
\hline Persentase skor kekuatan (\%) & & & 74,43 \\
\hline Kelemahan & & & \\
A. Pengendapan dana cukup lama dengan jumlah besar & 0,047 & 2,000 & 0,095 \\
B. Proses pencairan relatif lama & 0,051 & 1,750 & 0,090 \\
C. Pemberdayaan ekonomi RTM belum dijalankan & 0,063 & 1,500 & 0,094 \\
D. Simpanan anggota tidak berkembang & 0,046 & 1,250 & 0,058 \\
E. Fasilitasi pengembangan usaha anggota masih lemah & 0,076 & 1,000 & 0,076 \\
F. Tim verifikasi belum diperankan secara maksimal & 0,067 & 1,500 & 0,100 \\
G. Adanya syarat agunan memberatkan RTM & 0,073 & 1,250 & 0,091 \\
H. UPK belum memiliki legal lending & 0,035 & 1,750 & 0,061 \\
\hline Subtotal & & & 0,664 \\
\hline Persentase skor kelemahan (\%) & 1,000 & 25,57 \\
\hline TOTAL & & 2,597 \\
\hline
\end{tabular}

Tabel 5. Matriks EFE kegiatan SPP Kecamatan Semparuk

\begin{tabular}{lccc}
\hline Faktor Eksternal & Bobot & Rating & Skor \\
\hline Peluang & & & \\
A. Pasar kredit masih luas di luar perdagangan dan jasa & 0,116 & 3,750 & 0,435 \\
B. Banyak masyarakat miskin belum mengakses dana SPP & 0,120 & 3,500 & 0,422 \\
C. Peluang kerjasama pengembangan jaringan & 0,073 & 3,750 & 0,273 \\
D. Perekonomian yang sulit mendorong untuk berwirausaha & 0,067 & 3,000 & 0,201 \\
E. Masih banyak masyarakat terjerat rentenir & 0,102 & 3,000 & 0,307 \\
F. Kemajuan teknologi mempermudah pengelolaan keuangan & 0,080 & 3,000 & 0,239 \\
\hline Subtotal & & & 1,876 \\
\hline Persentase skor peluang (\%) & & & 70,69 \\
\hline Ancaman & 0,089 & 2,000 & 0,177 \\
A. Persaingan dengan bank & 0,070 & 2,000 & 0,141 \\
B. Persaingan dengan lembaga keuangan non-bank & 0,072 & 2,000 & 0,143 \\
C. Perubahan kondisi sosekpol yang bersifat dinamis & 0,107 & 1,250 & 0,134 \\
D. Ada kecenderungan ketergantungan terhadap dana SPP & 0,104 & 1,750 & 0,183 \\
E. Ancaman berkurangnya anggota kelompok pemanfaat & & & 0,778 \\
\hline Subtotal & & & 29,31 \\
\hline Persentase skor ancaman (\%) & 1,000 & & 2,653 \\
\hline TOTAL &
\end{tabular}

\section{Analisis Matriks IE}

Nilai IFE yang diperoleh 2,597 dan nilai EFE 2,653. Perpaduan dari keduanya menunjukkan bahwa strategi pemasaran terletak pada kluster $\mathrm{V}$, yaitu sel stabilitas yang dapat dikelola dengan strategi pertahankan dan pelihara (hold and maintain) melalui strategi penetrasi pasar dan pengembangan produk. Hasil identifikasi dari kekuatan, kelemahan, peluang dan ancaman perusahaan serta posisi persaingannya yang berada pada sel $\mathrm{V}$ selanjutnya digunakan untuk merumuskan alternatif strategi dengan menggunakan matriks SWOT.

\section{Analisis matriks SWOT}

Penyusunan strategi pada matriks SWOT dilakukan sesuai dengan hasil yang diperoleh dari matriks IE, dimana posisi kegiatan SPP terletak pada sel V, yaitu stabil. Pencocokan faktor strategi internal dan eksternal dilakukan dalam lingkup strategi penetrasi pasar dan pengembangan produk. Berdasarkan hasil evaluasi matriks IFE 
dan EFE, disusunlah matriks SWOT yang menghasilkan empat tipe strategi yang dapat dilakukan, yaitu strategi S-O, W-O, S-T, dan W-T. Hasil analisis SWOT dapat dilihat pada Gambar 4.

1. Meningkatkan pelayanan (S1,S2,S3,S4,S5, $\mathrm{S} 6, \mathrm{~S} 7, \mathrm{~S} 8, \mathrm{~S} 9, \mathrm{~S} 10, \mathrm{~T} 1, \mathrm{~T} 2, \mathrm{~T} 3)$

Ancaman yang patut diwaspadai adalah adanya bank dan LKM di wilayah kerja UPK, yaitu BPD, BRI, CU dan "Koperasi", yang juga melayani masyarakat pada segmen yang sama. Untuk itu, peningkatan pelayanan terhadap anggota dan pengurus kelompok SPP merupakan cara agar kerjasama dengan kelompok tetap berjalan. Jika pelayanan yang diberikan selama ini hanya kepada kelompok, berikutnya harus pula kepada anggota. Peningkatan pelayanan yang diberikan, terutama dalam hal mempercepat proses pencairan, menjaga sikap, penampilan, tutur sapa dan bahasa yang sopan sesuai dengan kearifan lokal dalam berinteraksi dengan anggota SPP. Apalagi interaksi yang dilakukan bukan hanya di kantor, tetapi juga di lapangan saat sosialisasi, musyawarah-musyawarah maupun kegiatan pembinaan. Strategi ini merupakan strategi bertahan dan memelihara.

2. Melakukan perluasan pasar dan jaringan pemasaran kredit (S1,S2, S5, S6, S9, S10, O1, O2, O3, O4, O5)

Pangsa pasar yang dilayani secara geografis lebih banyak terdapat di dua desa yang dekat dengan akses jalan raya berstatus jalan Provinsi. Melihat kondisi ini, mustinya tiga desa yang berada terpisah oleh sungai dan memiliki RTM lebih banyak bisa dikembangkan menjadi pangsa pasar potensial, meskipun sebagian sudah dilayani dengan dana SPP, bahkan dengan pengembalian angsuran lebih baik. Begitu pula dengan masih banyaknya masyarakat yang terjerat rentenir dan mayoritas peminjam dana selama ini adalah dari usaha perdagangan dan jasa yang secara bersamaan menunjukkan bahwa peluang yang besar pada usaha di luar jasa dan perdagangan untuk dibiayai. Kelebihan yang bisa dimanfaatkan adalah prosedur dan syarat pengajuan yang mudah, serta adanya reward and punishment akan menjadi daya tarik bagi kelompok perempuan di desa untuk ikut bergabung dan memanfaatkan dana SPP. Jaringan pemasaran yang bisa dimanfaatkan untuk memperluas jaringan pemasaran, misalnya PKK, kelompok pengajian, kelompok arisan, dan ada dua kelompok besar yang bisa dijadikan mitra UPK, karena mempunyai anggota yang memiliki tabungan yang relatif lebih besar dengan tanpa jasa/bunga sedikitpun. Ini merupakan implementasi strategi penetrasi pasar.

\section{Memaksimalkan peran pelaku program \\ (W1,W2, W3,W4,W5, W6, O3,O6) \\ BKAD sebagai pemegang amanah tertinggi di kecamatan harus dimaksimalkan perannya}

untuk memajukan UPK dan pengembangan kegiatan SPP. BP-UPK yang diberi tugas pengawasan oleh BKAD juga harus diberdayakan guna mengawasi, mengevaluasi, dan memberikan saran-saran perbaikan pengelolaan kegiatan SPP. Langkah memaksimalkan peran pelaku program untuk menutupi keterbatasan pengendapan dana, pencairan yang lama, pemberdayaan ekonomi RTM yang belum berjalan, simpanan yang tidak berkembang dan fasilitasi yang masih lemah sangat penting. Langkah tersebut diharapkan dapat mengakomodir kebutuhan kelompok SPP dan memanfaatkan peluang yang ada. Memaksimalkan peran TV secara teliti dalam memverifikasi anggota kelompok SPP yang ingin meminjam juga penting dilaksanakan.

Begitu pula memaksimalkan peran UPK, FK/FT, PL dan KPMD dalam membina kelompok tidak hanya sampai pengurusnya, akan tetapi sampai pada setiap anggotanya, tidak hanya orang yang sudah meminjam tetapi lebih diprioritaskan kepada keluarga RTM. Berbagai penelitian menunjukkan adanya kinerja yang baik atas pembayaran angsuran kredit mikro jika sering melakukan pertemuan kelompok, apalagi disertai dengan pendampingan dan pembinaan yang rutin. Begitu pula jika setiap pelaku memahami secara penuh akan filosofi dan pentingnya program ini jika terjadi hal-hal yang melemahkan UPK, karena adanya masalah hukum, maka para pelaku akan secara proaktif membela kepentingan masyarakat Kecamatan dengan mempertahankan lembaga dan dana abadi masyarakat tersebut.

Apabila sumber daya yang ada sudah maksimal, maka proses pencairan yang relatif lama bisa diatasi. Hal ini beralasan karena pelaku desa (Kepala Desa dan BPD) dan Kecamatan, terutama Camat akan ikut menyelesaikan, jika ada penunggakan pengembalian pinjaman dan memproses SPC lebih cepat segera setelah tahapannya selesai. Strategi ini merupakan strategi bertahan dan memelihara.

4. Mempertahankan komitmen pengembangan SPP (S1, S2, S3, S4, S5, S6, S7, S8, S9,

S10: 01, O2, O3,O5, O6)

Semangat program untuk mewujudkan masyarakat mandiri dan sejahtera harus dipertahankan dengan pelestarian dan pengembangan SPP. Pengembangan kelompok diarahkan sebagai lembaga pengelola simpanan dan pinjaman profesional dan akuntabel. Pengembangan kelembagaan kelompok SPP, secara badan hukum dapat menjadi Koperasi Simpan Pinjam. Komitmen penting yang harus dilaksanakan adalah menjalankan dan memprioritaskan pemberdayaan masyarakat miskin dengan strategi, teknik dan taktik yang baik, agar benar-benar bisa meningkatkan kesejahteraan dan kemandirian masyarakat miskin perdesaan. Jika program sudah menjalankan pemberdayaan sesuai tahapannya, yaitu membawa RTM dari tahap apatis dan ketergantungan (pra pemberdayaan) menuju 
tahap pra kritis dan pembebasan, maka kegiatan SPP juga akan berkembang dengan lebih baik. Strategi ini merupakan strategi bertahan dan memelihara.

\section{Penggolongan dan implementasi strategi}

Sesuai dengan hasil analisis matriks IE yang menunjukkan posisi perusahaan di sel $\mathrm{V}$ yang berarti posisi UPK stabil, strateginya tidak mengubah arah dengan menjaga dan mempertahankan (hold and maintain). Hasil analisis SWOT menggambarkan perlunya menjaga dan mempertahankan sebagai sebuah strategi utama, yaitu (1) mempertahankan komitmen terhadap pengembangan SPP, (2) meningkatkan pelayanan, (3) meningkatkan pembinaan kelompok, dan (4) memaksimalkan peran pelaku program. Keempat langkah strategi tersebut merupakan upaya organisasi terutama dalam meningkatkan kekuatan, menutupi kelemahan, sekaligus menghindarkan diri dari ancaman yang bisa datang dari luar. Untuk pemanfaatan peluang yang ada, dapat dilakukan dengan strategi penetrasi pasar dan pengembangan produk. Penetrasi pasar dilakukan dengan (1) perluasan pasar dan jaringan pemasaran kredit dan (2) meningkatkan promosi program, sedangkan pengembangan (diversifikasi) produk bisa dilakukan dengan pengembangan produk simpanan dan pinjaman.

Penetrasi pasar dan pengembangan produk merupakan strategi yang mengharuskan adanya upaya-upaya intensif, jika posisi kompetitif UPK dengan produk yang ada saat ini ingin membaik. Penetrasi pasar oleh UPK bisa berhasil jika melakukan penambahan jumlah tenaga penjualan, peningkatan pengeluaran iklan, penawaran produk-produk promosi penjualan secara ekstensif, atau upaya pelipatgandaan upaya-upaya pemasaran. Langkah operasional yang bisa dilakukan UPK adalah menduplikasi kemampuan SDM UPK dan KPMD untuk berpromosi dan menjual produk jasa pinjaman kepada RTM,

\begin{tabular}{|c|c|c|}
\hline Faktor Eksternal & $\begin{array}{l}\text { Kekuatan (S) } \\
\text { 1. Prosedur dan syarat pengajuan } \\
\text { kredit mudah dan ringan } \\
\text { 2. Ada pendampingan kelompok } \\
\text { 3. Pelaksanaan tanggung renteng } \\
\text { berjalan baik } \\
\text { 4. Musyawarah program efektif } \\
\text { memberikan informasi kepada } \\
\text { masyarakat } \\
\text { 5. Bantuan dana SPP sangat } \\
\text { bermanfaat bagi anggota } \\
\text { 6. UPK memiliki SDM bermutu } \\
\text { 7. Kontrol yang kuat dari } \\
\text { masyarakat luas } \\
\text { 8. Peran perempuan cukup dominan } \\
\text { dalam pengelolaan usaha } \\
\text { 9. Pemberlakuan reward and } \\
\text { punishment } \\
\text { 10. Pelayanan yang baik dari UPK }\end{array}$ & $\begin{array}{l}\text { Kelemahan (W) } \\
\text { 1. Pengendapan dana cukup } \\
\text { lama dengan jumlah besar } \\
\text { 2. Proses pencairan relatif } \\
\text { lama } \\
\text { 3. Pemberdayaan ekonomi } \\
\text { RTM belum dijalankan } \\
\text { 4. Simpanan anggota tidak } \\
\text { berkembang } \\
\text { 5. Fasilitasi pengembangan } \\
\text { usaha anggota masih } \\
\text { lemah } \\
\text { 6. Tim verifikasi belum } \\
\text { diperankan secara } \\
\text { maksimal } \\
\text { 7. Adanya syarat agunan } \\
\text { kepada RTM } \\
\text { memberatkan } \\
\text { 8PK belum memiliki legal } \\
\text { lending }\end{array}$ \\
\hline $\begin{array}{l}\text { Peluang (O) } \\
\text { 1. Pasar kredit masih luas di luar } \\
\text { perdagangan dan jasa } \\
\text { 2. Banyak masyarakat miskin belum } \\
\text { mengakses dana SPP } \\
\text { 3. Peluang kerjasama pengembangan } \\
\text { jaringan } \\
\text { 4. Perekonomian yang sulit } \\
\text { mendorong untuk berwirausaha } \\
\text { 5. Masih banyak masyarakat terjerat } \\
\text { rentenir } \\
\text { 6. Kemajuan teknologi mempermudah } \\
\text { pengelolaan keuangan. }\end{array}$ & \begin{tabular}{ll}
\multicolumn{1}{c}{ Strategi S-O } \\
a. & Mempertahankan komitmen \\
terhadap pengembangan SPP \\
(S1, S2, S3, S4, S5, S6, S7, S8, \\
S9, S10, 01, O2, O3,O5, O6) \\
b. Melakukan perluasan pasar dan \\
jaringan pemasaran kredit (S1,S2, \\
S5, S6, S9, S10, \\
O1,O2,O3,O4,O5)
\end{tabular} & 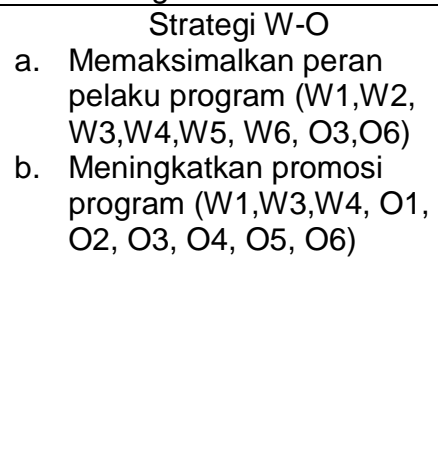 \\
\hline $\begin{array}{l}\text { Ancaman (T) } \\
\text { 1. Persaingan dengan bank } \\
\text { 2. Persaingan dengan lembaga } \\
\text { keuangan non bank } \\
\text { 3. Perubahan kondisi sosekpol yang } \\
\text { bersifat dinamis } \\
\text { 4. Ada kecenderungan } \\
\text { ketergantungan dana SPP } \\
\text { 5. Ancaman berkurangnya anggota } \\
\text { kelompok pemanfaat. }\end{array}$ & \begin{tabular}{ll}
\multicolumn{1}{c}{ Strategi S-T } \\
a. & Meningkatkan pelayanan \\
(S1,S2,S3,S4,S5, S6, S7, S8, S9, \\
S10, T1, T2, T3) \\
b. Meningkatkan pembinaan \\
kelompok (S2, S4, S6, S10, T4, \\
T5)
\end{tabular} & \begin{tabular}{ll}
\multicolumn{1}{c}{ Strategi W-T } \\
a. & Pengembangan produk \\
simpanan dan pinjaman \\
(W1,W2,W3,W4,W5, W6, \\
W7, W8, T1,T2,T3, T4, T5) \\
b. Meningkatkan pembinaan \\
kelompok (W1, W4, W5, \\
W8, T4, T5)
\end{tabular} \\
\hline
\end{tabular}


usaha mikro dan kecil yang ada, diikuti dengan pengeluaran biaya untuk operasional KPMD dengan nominal yang lebih manusiawi, dan lebih menggencarkan promosi dari pelaku-pelaku program yang lain. Pelaksanaan promosi harus diikuti dengan proses pemberdayaan yang benar. Usaha ini bisa jadi strategi efektif, karena pasar saat ini belum jenuh dengan jasa yang ada dengan tingkat pemakaian konsumen akan jasa kredit masih dapat ditingkatkan secara nyata.

Pengembangan produk simpanan dan pinjaman mungkin akan berdampak pada tambahan pengeluaran untuk penelitian dan pengembangan yang lebih spesifik. Penelitian lanjutan yang bisa dilakukan adalah untuk menentukan produk simpanan dan pinjaman apa yang cocok untuk setiap RTM dan kelompok SPP yang sudah ada. Pengembangan produk ini akan menjadi efektif, karena selama ini satu jenis produk simpanan yang sudah berjalan tiga tahun secara kinerja usaha sudah berhasil. Gagasannya di sini adalah menarik pemanfaat dana yang terpuaskan untuk mencoba produk baru (yang lebih baik) sebagai hasil dari pengalaman positifnya dengan produk jasa kredit UPK selama ini. Hal ini juga dilakukan untuk antisipasi dalam mempertahankan anggota pemanfaat dana SPP agar tidak beralih menggunakan produk serupa kepada pesaing UPK, yaitu CU, BRI, dan BPD, dan koperasi yang bergerak di jasa keuangan.

\section{Pemilihan alternatif strategi}

Tahap akhir dari analisis SWOT dari lembaga UPK adalah pengambilan keputusan alternatif strategi dengan menggunakan alat analisis Quantitative Strategic Planning Matrix (QSPM) berdasarkan pengembangan yang dilakukan David (2009). Penilaian daya tarik strategik menunjukkan bahwa strategi paling menarik untuk diterapkan adalah strategi untuk meningkatkan pelayanan dengan nilai 6,494 . Urutan strategi prioritas adalah sebagaimana Tabel 6 .

\section{KESIMPULAN}

1. Masalah yang teridentifikasi pada kegiatan simpan pinjam khusus perempuan adalah pemberdayaan ekonomi rumah tangga miskin belum dijalankan, tabungan anggota tidak berkembang, proses pencairan kredit relatif lama, belum maksimalnya fasilitasi kelompok dalam pengembangan usaha anggota dan pembuatan aturan-aturan kelompok.

2. Kekuatan yang dimiliki UPK antara lain prosedur dan syarat pengajuan kredit mudah dan ringan, ada pendampingan kelompok, pelaksanaan tanggung renteng berjalan baik, musyawarah program efektif memberikan informasi kepada masyarakat, bantuan dana SPP sangat bermanfaat bagi anggota, UPK memiliki SDM bermutu, kontrol yang kuat dari masyarakat luas, peran perempuan cukup dominan dalam pengelolaan usaha, pemberlakuan reward and punishment dan pelayanan yang baik dari UPK. Kelemahan UPK, yaitu pengendapan dana cukup lama dengan jumlah besar, proses pencairan relatif lama, pemberdayaan ekonomi RTM belum dijalankan, simpanan anggota tidak berkembang, fasilitasi pengembangan usaha anggota masih lemah, TV belum diperankan secara maksimal, adanya syarat agunan kepada RTM memberatkan, UPK belum memiliki legal lending. Peluang yang bisa dimanfaatkan, yaitu pasar kredit masih luas di luar perdagangan dan jasa, banyak masyarakat miskin yang belum mengakses dana SPP, peluang kerjasama pengembangan jaringan, perekonomian yang sulit mendorong untuk berwirausaha, masih banyak masyarakat terjerat rentenir dan kemajuan teknologi mempermudah pengelolaan keuangan. Ancaman bagi UPK adalah persaingan dengan bank dan lembaga keuangan non bank, perubahan kondisi sosial ekonomi dan politik yang bersifat dinamis, ada kecenderungan ketergantungan terhadap dana SPP dan ancaman berkurangnya anggota kelompok pemanfaat.

3. Alternatif strategi yang dapat dilakukan UPK Semparuk adalah meningkatkan pelayanan, melakukan perluasan pasar dan jaringan pemasaran kredit, memaksimalkan peran pelaku program, mempertahankan komitmen terhadap pengembangan SPP, meningkatkan promosi program, meningkatkan pembinaan kelompok dan pengembangan produk simpanan dan pinjaman. Strategi yang menjadi prioritas utama untuk diterapkan adalah meningkatkan pelayanan.

Tabel 6. Urutan prioritas strategi dari QSPM

\begin{tabular}{lcc}
\hline \multicolumn{1}{c}{ Alternatif strategi } & $\begin{array}{c}\text { Total nilai daya } \\
\text { tarik }\end{array}$ & $\begin{array}{c}\text { Urutan } \\
\text { prioritas }\end{array}$ \\
\hline Mempertahankan komitmen terhadap pengembangan SPP & 5,925 & 4 \\
Melakukan perluasan pasar dan jaringan pemasaran kredit & 6,053 & 2 \\
Meningkatkan pelayanan & 6,494 & 1 \\
Meningkatkan pembinaan kelompok & 5,501 & 6 \\
Memaksimalkan peran pelaku program & 5,997 & 3 \\
Meningkatkan promosi program & 5,598 & 5 \\
Pengembangan produk simpanan dan pinjaman & 5,408 & 7 \\
\hline
\end{tabular}




\section{DAFTAR PUSTAKA}

Arnaya, P.Y. dan M.S. Utama. 2012. Efektivitas Kegiatan Simpan Pinjam Khusus bagi Kaum Perempuan Rumah Tangga Miskin di Kecamatan Denpasar Timur. E-Jurnal Ekonomi Pembangunan Universitas Udayana, 1(1): 1-13.

[Bappenas] Badan Perencanaan Pembangunan Nasional. 2008. Pemberdayaan Koperasi, Usaha Mikro, Kecil, dan Menengah. http://www.bappenas.go.id. (22 Agustus 2010)

[BPS dan Kemenegkop UKM] Badan Pusat Statistik dan Kementerian Negara Koperasi dan UKM. 2008. Berita Resmi Statistik UKM BPS 2008. http://www.scribd.com. (22 Agustus 2010).

Dasaluti, T., A.V.S. Hubeis, dan E.S. Wiyono. 2010. Analisis Pengembangan Usaha Mikro dalam Mendukung Pemberdayaan Perempuan di Pulau Bunaken, Kota Manado, Sulawesi Utara. Manajemen IKM, 5(2): 157165.

David, F.R. 2009. Manajemen Strategis Konsep. Penerjemah: Dono Sunardi. Buku 1 Edisi XII. Salemba Empat, Jakarta.

Godquin, M. 2004. Microfinance Repayment Performance in Bangladesh: How to Improve the Allocation of Loans by MFIs.
Jurnal World Development, 32(11): 19091926, Printed in Great Britain.

Khandker, S.R. 2000. Savings, Informal Borrowing and Microfinance. Jurnal The Bangladesh Development Studies, XXVI(2\&3): 50-51.

Qoriah, S.N. dan T. Sumarti. 2008. Analisis Gender dalam Program Desan Mandiri Pangan (Studi Kasus: Desa Jambakan, Kecamatan Bayat, Klaten-Jawa Tengah). Sodality, 02(02): 209-234.

Rangkuti, F. 2010. Analisis SWOT: Teknik Membedah Kasus Bisnis. Gramedia Pustaka Utama, Jakarta.

Umar, H. 2002. Metode Riset Bisnis Dilengkapi Contoh Proposal dan Hasil Riset Bidang Manajemen dan Akuntansi. Gramedia Pustaka Utama, Jakarta.

2005. Strategic Management in Action. Gramedia Pustaka Utama, Jakarta.

[UPK] Unit Pengelola Kegiatan Kecamatan Semparuk. 2010. Laporan Keuangan UPK Kecamatan Semparuk Bulan Januari 2010. UPK Kecamatan Semparuk. Semparuk.

2011a. Laporan Keuangan UPK Kecamatan Semparuk Bulan Januari 2011. UPK Kecamatan Semparuk. Semparuk.

2011b. Laporan Keuangan UPK Kecamatan Semparuk Bulan Mei 2011 UPK Kecamatan Semparuk. Semparuk. 